\title{
First report of Berkeleyomyces basicola (synonymous: Thielaviopsis basicola) on roots of sweet potato (Ipomoea batatas (L.) Lam) in Argentina
}

\section{Primer reporte de Berkeleyomyces basicola (sinónimo: Thielaviopsis basicola) en raíces de batata (Ipomoea batatas (L.) Lam) en Argentina}

Julia A. Martino ${ }^{1}$, Liliana del Valle Di Feo ${ }^{1}$, Mauro Paccioretti ${ }^{1}$, Clara Adriana Contardi ${ }^{2}$, Miguel A. Sanchez ${ }^{3}$, Leandro I. Ortega ${ }^{4}$, Silvina E. Pastor ${ }^{1}$

Originales: Recepción: 18/10/2020 - Aceptación: 21/05/2020

Nota científica

\begin{abstract}
Symptomatic sweet potato cv Arapey INIA samples were collected from a commercial production field in Colonia Molina, Guaymallén department, Mendoza province, Argentina. They showed dark rounded lesions, sometimes coalescing with white granular mycelium. Fungus was obtained from symptomatic sweet potatoes, which represented the generalized infection that affected the crop. They were seeded in PDA with streptomycin sulfate and incubated for seven days at $21^{\circ} \mathrm{C}$, alternating white/black (UV400nm) light. Observations with an optical microscope revealed the presence of hyaline, not septated, cylindrical endoconidia with rounded ends. They were 8-16 $\mu \mathrm{m}$ length and 4-6 $\mu \mathrm{m}$ width. Phialides were 43-46 $\mu \mathrm{m}$ length, rounded bases (7-9 $\mu \mathrm{m}$ width) and tapering to the neck's tip (4-6 $\mu \mathrm{m}$ width). Brown chlamydospores (aleuriospores), 9-13 $\mu \mathrm{m}$ length and 8-12 $\mu \mathrm{m}$ width, in chains of 2-8 spores were observed. For molecular identification, total genomic DNA was extracted. ITS fragment of $565 \mathrm{pb}$ was amplified using ITS5/ITS4 primers and sequenced. The sequence indicated 99\% identity with Berkeleyomyces basicola (synonymous: Thielaviopsis basicola). This was deposited in GenBank as (KX580957) (CBS: C430.74, Gen Bank accession number AF275482.1). This is the first report of B. basicola in sweet potato in Argentina, a potential threat to storage root yields.
\end{abstract}

\section{Keywords}

Ipomoea batatas $\bullet \operatorname{root} \operatorname{rot} \bullet$ Chalara elegans $\bullet$ potato $\bullet$ sweet potato fungal disease

1 Instituto Nacional de Tecnología Agropecuaria. Instituto de Patología Vegetal (Argentina). 11 de Septiembre 4755 (ex-camino 60 cuadras km 5,5). X5020ICA. Córdoba. Argentina. * silvinapastor10@gmail.com

2 Instituto Nacional de Tecnología Agropecuaria. Agencia de Extensión Rural Luján de Cuyo. Mendoza. Argentina.

3 Consejo Nacional de Investigaciones Científicas y Técnicas. Unidad de Estudios Agropecuarios (Argentina). 11 de Septiembre 4755 (ex-camino 60 cuadras km 5,5). X5020ICA. Córdoba. Argentina.

4 Instituto Nacional de Tecnología Agropecuaria. Centro de Investigaciones Agropecuarias. Instituto de Fisiología y Recursos Genéticos Vegetales (Argentina) 11 de Septiembre 4755 (ex-camino 60 cuadras km 5,5). X5020ICA. Córdoba. Argentina.

* Julia A. Martino and Liliana del Valle Di Feo contributed equally to this study. 


\section{RESUMEN}

Muestras sintomáticas de batata cv Arapey INIA, fueron recolectadas en lotes de producción comercial en Colonia Molina, Guaymallén, Mendoza, Argentina. Estas presentaban lesiones redondeadas, oscuras, frecuentemente coalescentes, con micelio granuloso blanco. El hongo fue aislado a partir de batatas sintomáticas que representaban la infección generalizada del cultivo. Los aislamientos fueron sembrados en APG con sulfato de estreptomicina e incubados durante siete días a $21^{\circ} \mathrm{C}$ con alternancia de luz blanca/ luz negra (UV-400 nm). Las observaciones al microscopio óptico revelaron la presencia de endoconidios hialinos, no-septados, cilíndricos con extremos redondeados (8-16 x 4-6 $\mu \mathrm{m}$ ), fiálides (43-46 $\mu \mathrm{m}$ de largo) de base redondeada $(7-9 \mu \mathrm{m})$ y cuello que se estrecha hacia la punta $(4-6 \mu \mathrm{m})$. También se observaron clamidosporas marrones (aleuriesporas) de 9-13 x 8-12 $\mu \mathrm{m}$, en cadenas con 1-7 septos. El ADN genómico fue extraído para la identificación molecular. Un fragmento ITS de 565 pb fue amplificado usando los iniciadores ITS5/ ITS4 y secuenciado. La secuencia reveló $99 \%$ de identidad con Berkeleyomyces basicola (sinónimo: Thielaviopsis basicola) y está depositada en el GenBank como KX580957 (CBS: C430.74, GenBank accession number AF275482.1). Esta constituye el primer reporte de B. basicola en el cultivo de batata en Argentina y una amenaza potencial para la producción de raíces reservantes.

\section{Palabras clave}

Ipomoea batatas • podredumbre de raíz • Chalara elegans • enfermedad fúngica en batata

\section{INTRODUCTION}

Sweet potato (Ipomoea batatas (L.) Lam) is among the seven most important food crops worldwide. It has great potential not only for human consumption, but also for animal feeding and industrial use (4). It has been considered as a calorie source in many circumstances, such as in Japan when typhoons destroyed rice crops, or during the 1930s depression in the USA. Besides, storage roots can also be used for fermentation, as a source of starch for food processing, or production of chemical stocks, including organic acids (16). It is considered a subsistence crop as it can be produced with few inputs. Moreover, sweet potato tolerates stresses such as drought and, in the absence of frost, it can be left in the field to be harvested when needed (14).

The fungus B. basicola (synonymous T. basicola and Chalara elegans) $(20,21)$ is the causal agent of black root rot. This fungus infects a wide range of hosts, including plants from at least 15 families worldwide, including Argentina (9). On sweet potato (I. batatas), it was isolated from black rotted roots in China, Japan, Indonesia, Papua New Guinea, New Zealand and the USA (15).

B. basicola is a soilborne hemibiotrophic fungus. The infection cycle begins with a biotrophic phase followed by a necrotrophic phase (18). It can also be associated with hosts in a nonpathogenic manner (26) and is capable of saprophytic utilization of soil organic matter $(10,22)$. The life cycle of $B$. basicola has been described for tobacco (12), pansy (18) and cotton (17). Based on these descriptions, this cycle is divided into six major steps: (i) germination of spores; (ii) growth of the germ tube towards roots; (iii) attachment to root surface-the first contact and initial host-pathogen recognition; (iv) pathogen differentiation into infection structures and penetration into host cells; (v) establishment of a biotrophic phase; and (vi) conversion to necrotrophic phase (root rotting) and production of new spores.

B. basicola produces two types of spores, endoconidia (also known as phialospores) and chlamydospores (or aleuriospores), that could be produced singly or clustered as chains $(1,22)$. Two complex cell-wall systems have been observed in chlamydospores. An outer cell wall encloses the whole chlamydospore chain and each individual compartment possesses its own separate cell wall. Both cell walls are composed of an outer highly electron-dense layer and an inner layer, which appeares to be electron-transparent (8). In culture, 
endoconidia have been produced within $24 \mathrm{~h}$ and chlamydospores, within 3 days (24); each of these with some variations depending on the isolate and culture conditions.

The presence of the two types of spores and the shape of the chlamydospores are diagnostic morphological tools for the identification of the species. Since the endoconidia have the typical features of Chalara complex $(19,21)$, T. basicola was placed into this genus just like C. elegans. Nel et al. (2017), T. basicola was described as Berkleyomyces gen nov. and the current name is B. basicola.

Healthy nursery materials, fungicides, and crop rotations are important elements for disease control, but they require early diagnosis and pathogen detection in either plant, soil or water. Rapid and accurate identification and detection of $B$. basicola would improve diagnosis and prophylaxis (13).

Previously published works have shown black root rot caused by B. basicola on other crops in Argentina $(3,5)$. However, these crops do not share the same production environment with sweet potato in Mendoza. The symptoms observed in field sweet potatoes, clearly match those described for black root rot. Therefore, the hypothesis was that these symptoms are produced by B. basicola. The objective of this study was to identify the causal agent of sweet potato root rot in Argentina.

\section{MATERIALS AND METHODS}

Storage roots of sweet potato cv. Arapey INIA with black root rot symptoms were collected from a commercial field in Colonia Molina, Mendoza province, Argentina (-32.8316311,-68.7238142), in May 2017.

The fungus was isolated from three symptomatic roots, which represented the generalized infection that affected the crop. The isolates were obtained by removing mycelium of the rounded black, sometimes coalescing superficial lesions using a sterile needle (figure 1a, page 286). The lesions were 3-10 mm diameter, not deeper than $3 \mathrm{~mm}$ and with granular white mycelium dispersed on the surface (figure 1.b, page 286). The fungus isolates, morphologically identified as B. basicola $(2,6,11)$ were transferred to plates containing potato dextrose-agar plus streptomycin sulfate $(150 \mathrm{mg} / \mathrm{l})$. They were incubated for 7 days, at $21^{\circ} \mathrm{C}$ with $12 \mathrm{~h}$ alternation of white/black (UV-400 nm) light. An optical microscope (NIKON eclipse T $i$ ) was used to observe specific structures developed on colonies. The monosporic isolates were deposited in Instituto de Patología Vegetal-INTA mycobank (collection in process of registration). Molecular identification was performed through DNA extraction from a pure culture ( $\mathrm{N}^{\circ} 118$ strain) according to Dellaporta et al. (1983). A Polymerase Chain Reaction (PCR) of rDNA was carried out using ITS5/ITS4 primers (25) according to previously published conditions (23). The obtained PCR product was purified for sequencing and checked by BLAST analysis.

\section{RESULTS AND CONCLUSIONS}

Colonies initially white, turned brown after 7 days of incubation. Morphological features were consistent with those previously described $(2,6,11)$ : non septated, cylindrical, hyaline, endoconidia with rounded ends and 8-16 $\mu$ m length x 4-6 $\mu \mathrm{m}$ width. They emerged from 43-46 $\mu \mathrm{m}$ length phialides with rounded bases 7-9 $\mu \mathrm{m}$ width, tapering to the neck's tip (4-6 $\mu \mathrm{m}$ in width). Detected chlamydospores (aleuriospores) were 8-12 $\times 9-13 \mu \mathrm{m}$, arranged in chains of 2-8 spores, with thick brown walls and hyaline ends (figure 2, page 286).

An ITS fragment of $565 \mathrm{bp}$ from isolate, was amplified. The alignment analysis indicated $99 \%$ identity with the B. basicola collection, and the sequence was sent to GenBank (KX580957) (CBS: C430.74, GenBank accession number AF275482.1).

According to morphological and molecular features, B. basicola is the causal agent of sweet potato black root rot. This is the first report about sweet potato black root rot in Argentina, a potential threat to this crop in the Mendoza production area. 


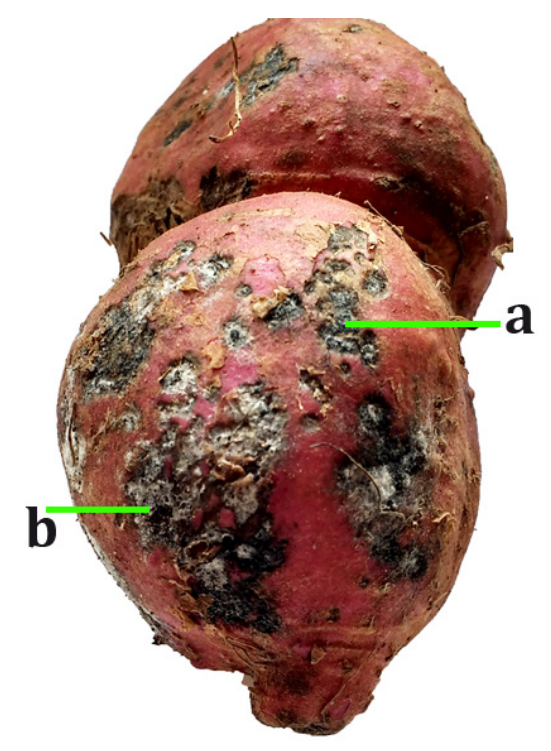

Figure 1. Sweet potato with typical black root rot symptoms. a- Black lesions. b- White mycelium on lesions.

Figura 1. Batata con síntomas típicos de podredumbre negra de raíz. a- Lesiones negras. b- Micelio blanco sobre lesiones.

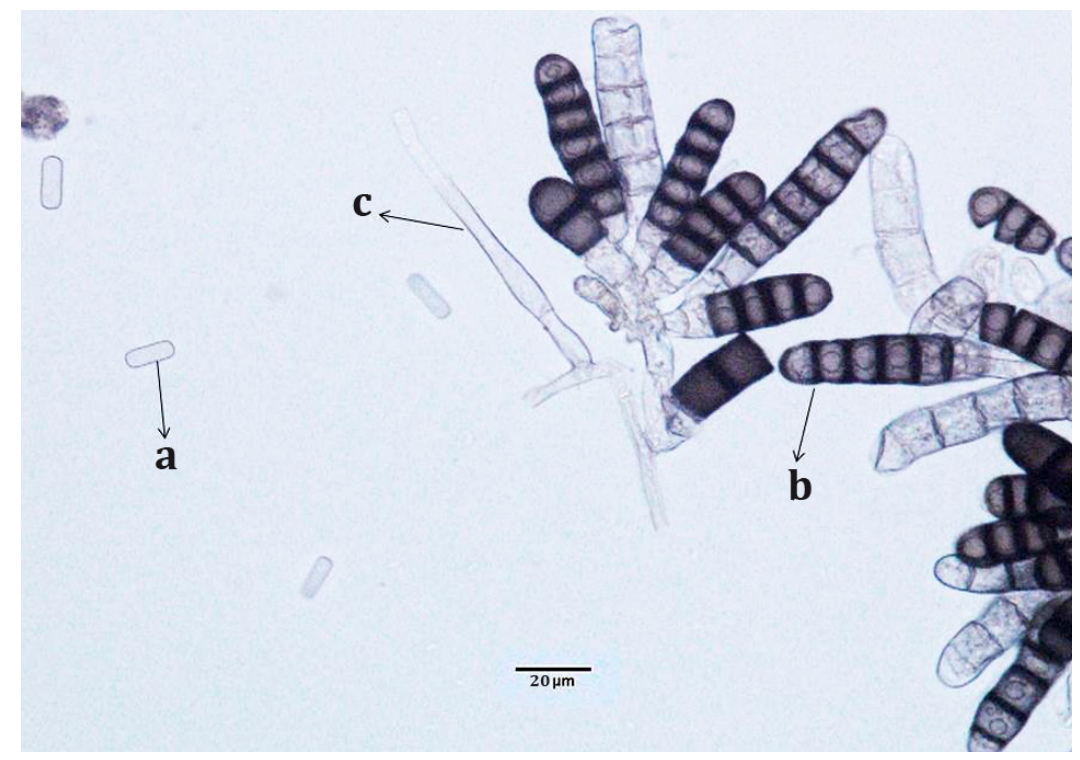

Figure 2. a- Endoconidium. b- Chain of chlamydospores. c- Phialide. Figura 2. a- Endoconidio. b- Cadena de clamidosporas. c- Fílide. 


\section{REFERENCES}

1. Abd Allah E. F.; Hashem A.; Bahkali A. H.; Al-Huqail A. 2011. First report of black root rot disease (Thielaviopsis basicola) of carrot in Saudi Arabia. African Journal of Microbiology Research 5(18): 2867-2869. DOI: 10.5897/AJMR11.107.

2. Barnett, H. L.; Hunter, B. B. 1998. Illustrated genera of imperfect fungi (No. Ed. 4). American Phytopathological Society (APS Press).

3. Barreto, D.; Fortugno, C.; 2005. Podredumbre de frutos. Enfermedades del Maní en Argentina. Editor/es: March, G. J.; Marinelli, A. D. p. 6.

4. Bovell-Benjamin, A. C. 2007. Sweet potato: A review of its past, present, and future role in human nutrition. Advances in food and nutrition research. 52: 1-59. DOI: http://dx.doi. org/10.1016/S1043-4526(06)52001-7.

5. Cabrera, M. G.; Álvarez, R. E.; Raimondo, M. R.; Cúndom, M. A.; Gutiérrez, S. A.; 2004. Importancia de las enfermedades de fin de ciclo de la soja, en el NEA. UNNE. Cátedras de Fitopatología y Cultivos II. p. 4.

6. Clark, C. A.; Moyer J. W. 1988. Compendium of sweet potato diseases. American Phytopathological Society. $74 \mathrm{p}$.

7. Dellaporta, S. L.; Wood, J.; Hicks, J. B. 1983. A plant DNA minipreparation: Version II. Plant Mol Biol Rep 1: 19-21. DOI: https://doi.org/10.1007/BF02712670.

8. Delvecchio V. G.; Corbaz R.; Turian G. 1969. An ultrastructural study of the Hyphae, Endoconidia and Chlamydospores of Thielaviopsis basicola. J. Gen. Microbiol. 58: 23-27. DOI: 10.1099/00221287-58-1-23.

9. Frezzi, M. 1960. Enfermedades del maní en la provincia de Córdoba (Argentina). Revista de Investigaciones Agrícolas. 14(2): 113-155.

10. Gayed S. 1972. Host range and persistence of Thielaviopsis basicola in tobacco soil. Canadian Journal of Plant Science. 52(6): 869-873. DOI: 10.4141/cjps72-150.

11. Goidànich, G. 1990. Manuale di patologia vegetale. Volume II. $4^{\circ}$ Ristampa. Edizione Agricole. Bologna. p. 1283.

12. Hood, M.; Shew, H. 1997. Initial cellular interactions between Thielaviopsis basicola and tobacco root hairs. Phytopathology. 87(3): 228-235. DOI: https://doi.org/10.1094/ PHYT0.1997.87.3.228.

13. Huang, J.; Kang, Z. 2010. Detection of Thielaviopsis basicola in soil with real-time quantitative PCR assays. Microbiological Research. 165(5): 411-417. doi:http://dx.doi.org/10.1016/j. micres.2009.09.001.

14. Karyeija, R.; Gibson, R.; Valkonen, J. 1998. The significance of sweet potato feathery mottle virus in subsistence sweet potato production in Africa. Plant Disease. 82(1): 4-15. DOI: https:// doi.org/10.1094/PDIS.1998.82.1.4.

15. Li, Q.; Harrington, T.; Li, J. 2016. Worldwide distribution of the sweet potato strains of Ceratocystis fimbriata. In: Phytopathology. Amer. Phytopathological Soc. 106(12): 3.

16. Loebenstein, G. 2008. Origin, distribution and economic importance. In: Loebenstein G.; Thottappilly, G. (eds) The Sweet potato. Springer. Dordrecht. DOI https://doi.org/10.1007/978-14020-9475-0_2

17. Mauk, P.; Hine, R. 1988. Infection, colonization of Gossypium hirsutum and G. barbadense, and development of black root rot caused by Thielaviopsis basicola. Phytopathology. 78(12): 1662-1667. DOI: 10.1094/Phyto-78-1662.

18. Mims, C. W.; Copes, W. E., \& Richardson, E. A. 2000. Ultrastructure of the penetration and infection of pansy roots by Thielaviopsis basicola. Phytopathology. 90(8): 843-850. DOI: 10.1094/ PHYTO.2000.90.8.843.

19. Nag Raj, T.; Bryce, K. 1975. Monograph of Chalara and Allied Genera. Waterloo, Ontario, Canada: Wilfrid Laurire University Press.(2017 Location of publication: Waterloo, Ont. Canada Record Number: 19761327541.

20. Nel, W. J.; Duong, T. A.; Wingfield, B. D.; Wingfield, M. J.; de Beer, Z. W. 2017. A new genus and species for the globally important, multihost root pathogen Thielaviopsis basicola. Plant Pathology. 67(4): 871-882.

21. Paulin-Mahady, A. E.; Harrington, T. C.; McNew, D. 2002. Phylogenetic and taxonomic evaluation of Chalara, Chalaropsis, and Thielaviopsis anamorphs associated with Ceratocystis. Mycologia. 94(1): 62-72.

22. Pereg, L. L. 2014. Black root rot of cotton in Australia: the host, the pathogen and disease management. Crop and Pasture Science. 64(12): 1112-1126. http://dx.doi.org/10.1071/CP13231.

23. Phan, H.; Ford, R.; Bretag, T.; Taylor P. 2002. A rapid and sensitive polymerase chain reaction (PCR) assay for detection of Ascochyta rabiei, the cause of ascochyta blight of chickpea. Australasian Plant Pathology. 31(1): 31-39. DOI: https://doi.org/10.1071/AP01056.

24. Shew, H.; Meyer, J. 1992. Thielaviopsis. In: Methods for research on soilborne pathogenic fungi. [Eds. L. L. Singleton; J. D. Mihail; C. M. Rush]. APS Press. St Paul. MN. 171-174.

25. White, T. J.; Bruns T.; Lee, S.; Taylor, J. 1990. Amplification and direct sequencing of fungal ribosomal RNA genes for phylogenetics. PCR protocols: a guide to methods and applications. 18(1): 315-322. DOI: https://doi.org/10.1016/b978-0-12-372180-8.50042-1.

26. Yarwood C. 1974. Habitats of Thielaviopsis in California. Plant Disease Reporter. 58(1): 54-56. DOI: $10.1080 / 00275514.1983 .12023725$. 